\title{
Discussing Competitiveness of Vietnam Logistics Industry
}

\author{
Vu Thi Kim Hanh (Corresponding author) \\ Lecturer in Faculty of Commerce, Van Lang University \\ 69/68 Dang Thuy Tram Street, Binh Thanh District, Ho Chi Minh City, Vietnam \\ E-mail: vtkhanh.ti@gmail.com, vuthikimhanh@vanlanguni.edu.vn
}

Received: June 23, 2020 Accepted: June 29, 2020 Published: July 2, 2020

doi:10.5296/jad.v6i2.17294 URL: https://doi.org/10.5296/jad.v6i2.17294

\begin{abstract}
Vietnam country is in the process of both deep and wide integration with the world economy. The world market is wide open for Vietnamese goods and reverse. Towards economic integration and opening up, logistics industry increasingly plays an extremely important role. Porter (1991), argues that logistics is a functional area that contributes to value creation. Logistics is a tool to link activities in the global value chain such as supply, production, distribution, and market expansion for economic activities. According to the Council of Supply Chain Management Professionals (CSCMP, 2013).

Although knowing the role of Logistics for the economy, the capacity and contribution of logistics to the Vietnamese economy is still small, the Vietnam LPI is just be arranged at from 39 to 64 in the period from 2007 to 2018 according to the officially announced figures of the World Bank.

From the above reasons home logistics industry, the author who is teaching Logistics supply chain management industry at Van Lang University, Ho Chi Minh City. Ho Chi Minh, Vietnam, take a pen to write down this research.

This essay analyzes the current situation, related issues and difficulties related to the competitiveness of Vietnam's logistics industry. Uses qualitative methods, uses analysis, comparison, synthesis and description tools to clarify the theoretical basis of the competitiveness of Vietnam's Logistics service industry, and identify indicators Pepper is used to measure the competitiveness of Vietnam's logistics industry. Uses quantitative research methods, through data collection, data analysis, using statistical methods, to determine the current status of Vietnam's logistics service industry capacity since 2007 to 2018, and find out what factors affect the competitiveness of the logistics service industry.




\section{Ml Macrothink}

Proposing key views and solutions to improve the competitiveness of Vietnam's logistics service industry.

Keywords: logistics, LPL, competitiveness, customs, forwarders, shipments

\section{Introduction}

Logistics is a tool to link activities in the global value chain such as supply, production, distribution, and market expansion for economic activities.

As the global market develops with technological advances, especially the opening of markets in developing and underdeveloped countries, Logistics is considered by managers as a tool and a means to connect the fields. Different areas of enterprise strategy. Logistics creates the usefulness of time and place for business activities. Developing logistics services effectively will contribute to increasing the competitiveness of the economy and the country.

Vietnam country is currently in the process of both deeper and larger integration with the world economy. The world market is wide open for Vietnamese goods and vice versa. Integration creates many great opportunities for a developed country, but it is also a great challenge if we do not have strong internal resources. In order to create strengths for the economy, we need to improve our competitiveness not only in the fields of agriculture, industry and science but also in trade and services, in which Logistics plays a key role in renew the growth model and restructure the economy as well as improve the quality, efficiency, rapid and sustainable development in our country. According to Bowersox \& Closs (1996), the true excitement of logistics is not to halt or reduce costs but to come from an understanding of how selected companies position their logistics capabilities to gain a competitive advantage.

According to the announced officially statistics of the World Bank, the LPI (Logistics Performance Index) in the past 11 years of Viet Nam below.

\begin{tabular}{|l|l|l|l|l|}
\hline Country & Year & LPI rank & LPI score & Total country \\
\hline Vietnam & 2007 & 53 & 2.89 & 150 \\
\hline Vietnam & 2010 & 53 & 2.96 & 155 \\
\hline Vietnam & 2012 & 53 & 3.00 & 155 \\
\hline Vietnam & 2014 & 48 & 3.15 & 160 \\
\hline Vietnam & 2016 & 64 & 2.98 & 160 \\
\hline Vietnam & 2018 & 39 & 3.27 & 160 \\
\hline
\end{tabular}


Decision No. 200 / QD-TTG of the Prime Minister of Vietnam, issued on 14 February 2017, approving the action plan to enhance competitiveness and develop Vietnam's logistics industry to 2025, Focusing on improving the competitiveness, investing and doing beautiful the picture of logistics service provider in Vietnam. To develop enterprises providing logistics services in terms of quantity, size, human resource, and high competitiveness in domestic and international markets. The State plays the role of supporting and creating a favorable environment for Vietnam to improve its competitiveness and develop its logistics services. By 2025 , the contribution of logistics service industry to GDP will reach $8 \%-10 \%$, service growth rate will reach $15 \%-20 \%$, outsourcing logistics services will reach $50 \%-60 \%$. , logistics costs fall to $16 \%-20 \%$ of GDP, ranked by the world's logistics capacity index (LPI) in the world at 50 th level or higher.

Directive 21 / TC-TTg of the Prime Minister of Vietnam, dated on 18 July 2018, the instruction on promoting the implementation of solutions to reduce logistics costs, and effectively connect the transport infrastructure. The overall task of the ministries, branches and localities, according to their assigned functions and tasks, has a specific program to implement the action plan to improve competitiveness and develop Vietnam logistics services by 2025 .

Resolution No. 02 / NQ-CP of Vietnam Government, issued on January 1, 2019, on continuing to carry out the main tasks and solutions to improve the business environment, enhance national competitiveness in 2019 and orientations to 2021. One of the main goals and targets to improve the business environment, improve national competitiveness in 2019, orientations to 2021 is to upgrade the logistics performance in the coming time to step up 5 10 higher level.

Decision No. 708 / QD-BCT dated March 26, 2019, on approving the plan to improve Vietnam's Logistics Performance Index. The objective of improving Vietnam's ranking in the logistics performance index (referred to as LPI) published by the World Bank (WB) from now to 2025 to 5-10 ranks, contributing positively to improving improve the business environment, cut costs, improve the competitiveness of Vietnam's logistics service provider, enhance innovation capacity, contribute to successfully implementing the Government's resolution on development. Socioeconomic.

Recognizing the importance of the role of Logistics industry to the country, the author conducted this study to find practical evidence and suggest solutions to improve the competitiveness of Vietnam's Logistics industry. In line with the Government's guidelines and expectations.

\section{Literature Review and Analysis Framework}

Logistics: in order to understand the meaning of Logistics, below is some definitions of Logistics under different points of view of the Economist and Logistics specialists.

According to the Council of Supply Chain Management Professionals (CSCMP, 2013), "Logistics is part of a planned supply chain process, which effectively implements and controls the flow and storage of goods and services and related information from the point of 
view". Departing to the point of consumption to meet customers' requirements. Heskett et al (1973), he argued that "Logistics is the management of all activities that facilitate the movement and coordination of supply and demand in creating utilities of time and place". Under the point of Porter (1991), he said "Logistics is a functional area contributing to the creation of value". However, the others have other definitions like "The true excitement of logistics is not cost containment or reduction but comes from understanding how select firms position their logistical competency to gain competitive advantage" (Bowersox, donald \& Closs, 1996). "Logistics is the art of managing the flow of physical material and information from the source to the user" (Capacino, 1997). "Reverse Logistic is the process of planning, implementing and controlling the efficient, cost effective flow of raw materials" (Rogers et al, 1999). "Logistics is the flow of material information and money between consumers and suppliers" (Frazzle, Edward 2002). "Encompasses all of the information and material flows throughout an organization and inter organizations." (Gunasekaran, 2003). "Logistics involves getting in the right way, the right quantity, right quality in the right place at the right time for the right customer at the right cost." (Mangan et al., 2008). "Logistics is a function made of many sub-functions and many sub-systems each of which has been and may still be treated as a distinct management operation. There is a need to adopt a more holistic view of these different operations in order to take into account how they interrelate and interact with one another" (Rushton et al, 2010). "Logistics is "the process of strategically managing the acquisition, movement and storage of materials, parts and finished inventory (and the related information flows) through the organization and its marketing channel in such a way that current and future profitability is maximized through the cost effective fulfillment of orders" (Christopher, 2011). Accordance with the Decision No.: 200/QD-TTg dated 14 Feb 2017 issued by the Prime Minister of Vietnam in Hanoi, Vietnam, Logistics is an important service sector in the overall structure of the national economy, plays the role in support, connection and improvement of the social - economic development of the whole country as well as that in each locality, and takes part in the improvement of the economic competitiveness.

Competition and competitiveness: Competition theory and Competitiveness can now be divided into Classical and Modern schools.

Classical schools: (A. Smith, 1776) said "the thought of competition and economic freedom is aimed at opposing State intervention. Supplementing that view". Under the view of point of (John Stuart Mill, 1945), he argued that "upholds business freedom and opposes government intervention in (private)".

Modern schools: (J. Schumpeter, 1983) explained "the concept of competition to information-based and knowledge-based economies. Forms of combining competitive elements in the competition process must take advantage of technological advances and innovations, while emphasizing the role of the company, the talents of enterprises are recognized and need to be opened. wide range of operating environment for them to promote their creativity and talent competition, his creative theory points out creativity on three dimensions: 1- Innovating technology and using new techniques; 2- Innovating institutions to exploit the market and control the supply of new raw materials; 3 - Innovative management, application of organizational forms and new enterprise management". 
However, the research on competition of (Michael Porter, 2012) is quite comprehensive from the level of enterprises, industries to the nation, covering all areas of manufacturing and services. Competition is determined to be the source of economic progress in any country and is the foundation for highly productive citizens and abundant life. Because only enterprises can create wealth, not government, the focus should be on the micro-economic analysis of economic growth.

Besides, there are other concepts of competition and competitiveness:

"Compete is meaning to compete with each other" (Neufeldt, 1996). "Competition is an event in which individuals or organizations compete to achieve results that not everyone wins" (Wehmeier, 2000). "Competition is understood at the level of the enterprise, it is the struggle or scramble from some competitors about customers, market shares or resources of enterprises. However, the nature of competition today is not to destroy It is the business that has to create and bring customers higher or newer added value than their competitors so that they can choose themselves without coming to competitors" (Michael Porter, 1996). "Want to create competitiveness, requires businesses to create and get their own competitive advantages.

Competitiveness of Logistics: Accordance with the Decision No.: 200/QD-TTg of the Prime Minister of Vietnam, dated 14 February 2017 in Hanoi, Vietnam, in order to increase Logistics Competitiveness, the main groups of tasks below have to be actioned.

- Improving policies and laws on logistics services.

- Completing the logistics infrastructure.

- Strengthening business capacity and service quality.

- Developing the market of logistics services.

- Training, raising awareness and quality of human resources.

- Other tasks.

Base on World Bank: The components analyzed in the International LPI were chosen based on recent theoretical and empirical research and on the practical experience of logistics professionals involved in international freight forwarding, they are:

- The efficiency of customs and border management clearance ("Customs").

- The quality of trade and transport infrastructure (Infrastructure").

- The ease of arranging competitively priced shipments (Ease of arranging shipments").

- The competence and quality of logistics services - trucking, forwarding, and customs brokerage ("Quality of logistics services").

- The ability to track and trace consignments ("Tracking and tracing"). 
- The frequency with which shipments reach consignees within scheduled or expected delivery times ("Timeliness")

The previous researches related to Logistics and Logistics competitiveness

(Ruslan Beysenbaev and Yuri Dus, 2019), "Proposals for improving the Logistics Performance Indexx", The purpose of their study was to propose ways for improving the current Logistics Performance Index published by the World Bank. The Logistics Performance Index is based on a global survey of logistics experts, which can be biased towards a subjective view on different countries' logistics systems, which leads to a potentially skewed rating. They (the authors) proposed a modified index that qualitatively and quantitatively represents an objective view of 159 countries' logistics systems and subsystems, based on international statistical data, which can be used as a benchmarking tool for governments.

(Volkan Yavas and Yesim DenizOkan-Ozen, 2020), "Logistics centres in the new industrial era: A proposed framework for logistics centre 4.0", studied and focused on the transformation of logistics centres in Industry 4.0. Its purpose to prove the important criteria for logistics centres in Industry 4.0 by considering link to traditional logistics centres practices and proposing a framework for new logistics centres. The results of their study be useful for logistics centre's professionals in transition process, and new research topics may be derived for academics. The highlights of their research are: Focus is on transformation of logistics centers in Industry 4.0, Traditional logistics center operations are linked to Industry 4.0 technologies, Fuzzy DEMATEL is used as methodology, and A framework for Logistics Center 4.0 is proposed.

(Xiongfeng Pan, Mengna Li, Mengyang Wang, Tianjiao Zong, and Malin Song, 2020), “The effects of a Smart Logistics policy on carbon emissions in China: A difference-in-differences analysis", the science paper concentrated on Smart Logistics distribution system which is is a comprehensive logistics system supported by advanced information technology. Meaning that theri research aims to improve the operation efficiency of the logistics industry and reduce carbon emissions by optimizing resource allocation. This paper used the binary choice model to investigate the main factors influencing the establishment of Smart Logistics in Chinese cities, and whether carbon emissions are the cause of the establishment of Smart Logistics. The results reveal that freight volume, logistics employment, and total social retail are important factors determining whether a city should establish Smart Logistics or not. Additionally, the decision whether to establish Smart Logistics is an exogenous policy variable to carbon emissions. The implementation of SLP can restrain carbon emissions significantly, with a continuous impact in the second year. Based on the findings of this paper, a series of policy implications with respect to promote the development of Smart Logistics were proposed. The highlights of their study are; A difference-in-differences (DID) model was constructed in this study, The effect of Smart Logistics policy on China's carbon emissions was investigated, Freight volume, employment, and total social retail are key influencing factors, and The Smart Logistics policy can restrain carbon emissions significantly. 
(Angel Corberan, Mercedes Landete, Juanjo Peiro, and Francisco Saldanha, 2020), "The facility location problem with capacity transfers", Their study explored the concept of capacity transfer in the context of capacitated facility location problems. This is accomplished by assuming that facilities with surplus capacity/production can cooperate with those facing shortage by transferring part of that capacity/production. Such a transfer incurs a cost that nonetheless may be compensated by savings both in the installation costs and in the distribution costs. Generally, this research focused and investigated a problem that is at the core of more comprehensive models emerging in the context of logistics network design.

(Takanori Sakai, Adrien Beiat, and Adeline Heitz, 2020), "Location factors for logistics facilities: Location choice modeling considering activity categories", the study of them had discovered the highlights are Heterogeneity on location factor effects was identified by activity category, Zoning has the dominating effect for newly developed logistics facilities, and The importance of accessibility is dependent on activity category and situation. Their research attempts to fill the research gap by analyzing the location choices for logistics facility development. Using the data from the Paris Region, we characterize the locations and activities of logistics facilities and estimate a logistics facility location choice model for each activity category. The analysis reveals the key locational characteristics that influence logistics facility locations, such as zoning regulations, wholesale job accessibility, population density, and the accessibility to autoroute (controlled-access highway), as well as the heterogeneity in the effects of these characteristics by activity category. Zoning and traditional clusters play a significant role for the locations of newly developed logistics facilities, which underlines the importance of public policies for logistics land use in the Paris region. The effect of the accessibility to population is identified for the group of facilities which serve for retail shops and end-consumers only under the assumption that alternative locations are limited to specialized economic activity/logistics zones, indicating that population accessibility is a secondary factor to the designation as the specialized zone. Zoning changes to/from economic activity/logistics zones may cause significant impacts on the spatial distribution of logistics facilities, and thus, the distribution of goods vehicle traffic flow.

Luis C. Blancas, John Isbell, Monica Isbell, Hua Joo Tan, Wendy Tao, are World Bank officials with contributions from some independent experts (2014) "Effective logistics, the key to Vietnam improve competitiveness ", The analytical model used in the report is based on 3 main key contents corresponding to 3 objectives (1) identifying and clarifying the components of logistics costs in Vietnam. Nam, (2) select challenges and opportunities to reduce logistics costs and improve competitiveness that the Vietnamese government needs to pay attention to with the highest priority in the next 5-10 years, (3) propose infrastructure and policy development solutions to address the selected priority issues. Activities carried out within the framework of the research methodology of the report: (1) Carry out an overview of literature from multiple sources,

(2) Conduct market research to quantify descriptions, (3) Collecting opinions directly from the units participating in the transport field through detailed questionnaires set up by relevant domestic and foreign stakeholders, (4) completing the questionnaire for exporting units. 
Import via online survey tool. Four businesses completed the above online questionnaire. The results were imported into the main file for import-export units, (5) conducted interviews with 4 Vietnamese ministries and 4 industry and trade associations, (6) summarized the list of key existing issues based on the analysis of interview records, market research results, literature reviews, etc., (7) offer recommendations on state solutions and public-private partnership initiatives to overcome shortcomings. at having the highest priority selected.

Researchers Pietro Evangelista of the University of Naples in Italy, Edward Sweeney and Claudia-Maria Wagner of the National Research Institute of Transport \& Logistics and and the Institute of Technology Research in Dublin, Ireland (2009) "ICT innovation diffusion in small logistics service providers: An empirical survey", studied the role of information and communication technology in the innovation process of small third-party Logistics providers (3PL). Based on quantitative evidence, through a recent survey conducted on the Italian 3PL market, an analysis of how information and communication technology is used to support innovation and restraint factors. prevent and facilitate the use of information and communication technology in those companies. The meaning of supply chain innovation management is drawn from research and management perspectives. The basic research hypothesis is that the effective application of information and communication technology innovation has the potential to improve the competitiveness of small 3PLs. This improvement depends on an understanding of the main processes, drivers, and assistants. Quantitative research through questions and questions surveyed in Rome and Milan Italy. The study found that the 3PLs need to focus on a number of key goals, including the deployment of information and communication technologies. Considering that customer demand for performance and sophistication is accelerating, improving these areas is a must for 3PL. The capacity of emerging information and communication technologies is increasing at a rapid pace and its effective adoption is likely to greatly enhance the competitiveness of small 3PLs.

Professor Jack G.A.J. van der Vorst of the Logistics and Operations Research Department of Social Sciences, Wageningen University, Wageningen, Netherlands, economist Carlos A. da Silva of the United Nations Food and Agriculture Organization Rome, Italy, and Associate Professor Jacques H. Trienekens of the Department of Social Science Supply Chain Management, Wageningen University, Netherlands (2007), "Agro-industrial supply chain management: concepts and applications" studied and demonstrate the design of a Logistics system depends on the performance goals of the system relative to the markets it wants to provide. A well-known management principle is that the nature of the demand for a product needs to be carefully considered before the supply chain strategy is designed. When product cost is the main issue, the supply chain must be efficient; When quality and speed are more important to customers, the supply chain needs to be met and guaranteed. Today, the supply chain is expected to be extremely flexible, responsive, and low-cost, to meet constantly changing consumer needs.

Yenchun Jim Wu of National Taiwan University, Mark Goh of National University of Singapore, Chih-Hung Yuan of China University of Electronic Science and Technology, and Shan Huen Huang of Kaosiung National University and Faculty of Technology Study of Taiwan (2019) "Collaboration on logistics management research in Asia" aims to study the 
status of Logistics management in Asia. The research focuses on topics of interest and level of research cooperation in developing Logistics theory and specific knowledge for Asia. Using a mixed method, namely content analysis as the main method, and social network analysis as a supportive research method, and Logistics management research in Asia from a number of peer review magazines. about supply chain management and logistics. The study establishes an overall picture of supply chain management and Logistics research in Asia, but the study still lacks clarity on the Logistics management research conducted in this area.

Viet Linh Dang, Gi Tae Yeo (2018), "Weighing the Key Factors to Improve Vietnam's Logistics System ", The Asian Journal of Shipping and Logistics, April 2018, studied indicates a direction for the Vietnam government to follow in implementing the ideal investment prioritization and the appropriate regulations for the improvement of its logistics system. The results reveal that the optimal order for the improvement of Vietnam's logistics system are logistics costs, logistics services, logistics infrastructures, connections between logistics components, institutional frameworks, and technology. The study also provides logistics stakeholders with increased insight into the status of Vietnam's logistics system and the appropriate strategies for achieving the goals of its government.

Ruth Banomyong, Vinh V. Thai, Kum Fai Yuen (2018) "Assessing the National Logistics System of Vietnam", The Asian Journal of Shipping and Logistics. Volume 31 Number 1 March 2015 pp. 021-058, was to present and analyze the current situation regarding the capability of the national logistics system in Vietnam. The findings can help foreign investors, international logistics providers wanting to provide their services in Vietnam to understand the logistics context within the country. These findings are also helpful for policy makers in Vietnam on how to improve their national logistics system. This study proposes a template to assess national logistics systems and provides an in-depth understanding of logistics in Vietnam, a country that has not been much studied in the literature.

Thanh Thuy NGUYEN (2016), “An Investigation of the Vietnamese Shipping Industry and Policy Recommendations for Profound Participation into ASEAN Integration", The Asian Journal of Shipping and Logistics, 32(2) (2016) 081-088, the researcher was aim of this paper is to examine the Vietnam shipping industry and consider possible changes in policy led factors to facilitate the country's full participation in the ASEAN integration.

Vu Hai Nam (2019), "The Strategic Development in Logistics in Vietnam", EJERS, European Journal of Engineering Research and Science Vol. 4, No. 6, June 2019, studied the characteristics of Logistics Vietnam, practical performance in 2005, 2011, 2018, based on the PLI index published by the World Bank as of 2018, as well as analyzing the transport shops. From there, propose solutions for developing Vietnam Logistics such as enhancing technology application, promoting linkages and equitization, to ensure the supply of a complete logistics chain like foreign enterprises, promoting cooperation. between Vietnam Seaport Association and Vietnam Logistics Association, to enhance cooperation in exchanging information related to cargo handling and port cargo handling processes, in order to minimize seaport service charges, arrival and departure times of trains.

Analysis framework. 


\section{Logistics Competitiveness}

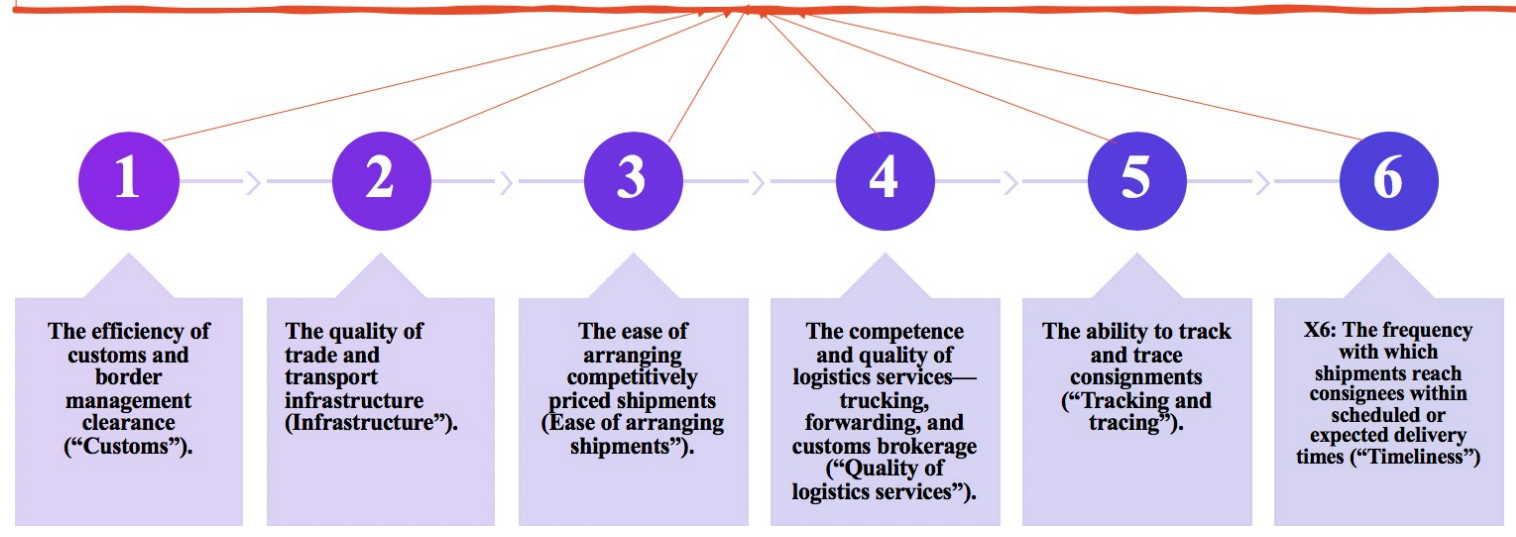

\section{Research Method and Data}

\subsection{Research method}

Statistics and analysis are used to study the status of logistics industry in the years from 2007 to 2018. The author then uses multivariate linear regression to analyze the relationships between the dependent variable Y which is Vietnam' logistics competitiveness and a number of independent variables $\mathrm{X}$, they are;

Y: Vietnam's logistics competitiveness

$\mathrm{X}$ : seven factors that create and directly affect the competitiveness of Vietnam's logistics industry as follows:

$\mathrm{X} 1$ : Customs, it is the efficiency of customs and border management clearance.

X2: Infrastructure, meaning the quality of trade and transport infrastructure.

X3: international shipments (Ease of arranging shipments), means that the ease of arranging competitively priced shipments.

X4: Logistics competence (Quality of logistics services), can be understood that it proves the competence and quality of logistics services - trucking, forwarding, and customs brokerage.

X5: Tracking and Tracing, showing the ability to track and trace consignments

X6: Timeliness, describing the frequency with which shipments reach consignees within scheduled or expected delivery times.

\subsection{Data Source}

The data sources are almost used from world bank, and also searched from Vietnam Customs, 


\section{Macrothink Institute ${ }^{\mathrm{TM}}$}

Vietnam General Statistics Office, Vietnam logistics association, and inherits the results of empirical studies from the previous authors.

\section{The research results}

\subsection{Vietnam LPI score card: analyzing the fluctuation of Vietnam LPI from 2007 to 2018.}

In the year 2007, Vietnam LPI rank was 53 by LPI score was 2.89 , it was a little bright in the three years after, and even though gained the LPL score at 2.96 but the rank s was similar level. The same situation was happened in 2012 that the LPI score was 3, it nevertheless the Vietnam rank kept the same 53. The two years after in 2016 was better with score was 3.15 and rank was 48 . It was significantly black situation that the line was jumped down from rank 48 to 64 with score only 2.98. However, in the year 2018 that was the best of Vietnam with rank was 39 and score was 3.27.

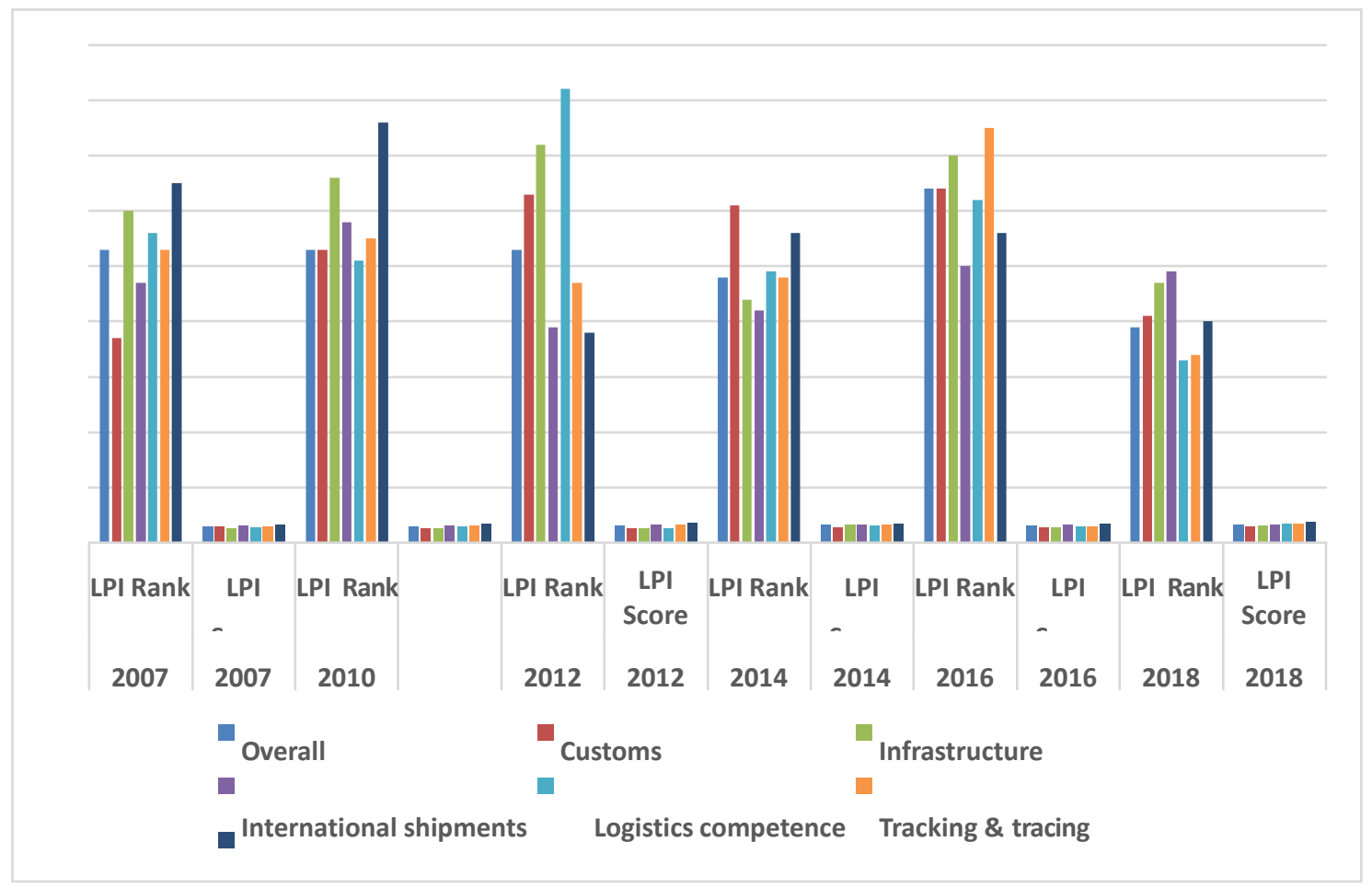

Figure 1. Vietnam IPL rank and scores from 2007 to 2018

Source: The author analyzed and built chart through data sources extracted from the world bank

Based on the chart above, we can realize two following notices:

- If the LPI scores are increased, it will be proved that service quality was improved

- The LPI score was higher, it does not mean that its rank be increased 
Table 1. Rank and score of LPI of Vietnam in 2007

\begin{tabular}{|c|c|c|c|c|c|c|c|c|c|}
\hline Country & Year & & Overall & Customs & Infrastructure & $\begin{array}{l}\text { Internationa } \\
\text { shipments }\end{array}$ & $\begin{array}{l}\text { Logistics } \\
\text { competence }\end{array}$ & \begin{tabular}{|l|} 
Tracking \\
$\&$ \\
tracing
\end{tabular} & Timeliness \\
\hline Vietnam & 2007 & $\begin{array}{l}\text { LPI } \\
\text { Rank }\end{array}$ & 53 & 37 & 60 & 47 & 56 & 53 & 65 \\
\hline Vietnam & 2007 & $\begin{array}{l}\text { LPI } \\
\text { Score }\end{array}$ & 2.89 & 2.89 & 2.5 & 3 & 2.8 & 2.9 & 3.22 \\
\hline Vietnam & 2010 & $\begin{array}{l}\text { LPI } \\
\text { Rank }\end{array}$ & 53 & 53 & 66 & 58 & 51 & 55 & 76 \\
\hline Vietnam & 2010 & $\begin{array}{l}\text { LPI } \\
\text { Score }\end{array}$ & 2.96 & 2.68 & 2.56 & 3.04 & 2.89 & 3.1 & 3.44 \\
\hline Vietnam & 2012 & $\begin{array}{l}\text { LPI } \\
\text { Rank }\end{array}$ & 53 & 63 & 72 & 39 & 82 & 47 & 38 \\
\hline Vietnam & 2012 & $\begin{array}{l}\text { LPI } \\
\text { Score }\end{array}$ & 3 & 2.65 & 2.68 & 3.14 & 2.68 & 3.16 & 3.64 \\
\hline Vietnam & 2014 & $\begin{array}{l}\text { LPI } \\
\text { Rank }\end{array}$ & 48 & 61 & 44 & 42 & 49 & 48 & 56 \\
\hline Vietnam & 2014 & $\begin{array}{l}\text { LPI } \\
\text { Score }\end{array}$ & 3.15 & 2.81 & 3.11 & 3.22 & 3.09 & 3.19 & 3.49 \\
\hline Vietnam & 2016 & $\begin{array}{l}\text { LPI } \\
\text { Rank }\end{array}$ & 64 & 64 & 70 & 50 & 62 & 75 & 56 \\
\hline Vietnam & 2016 & $\begin{array}{l}\text { LPI } \\
\text { Score }\end{array}$ & 2.98 & 2.75 & 2.7 & 3.12 & 2.88 & 2.84 & 3.5 \\
\hline Vietnam & 2018 & $\begin{array}{l}\text { LPI } \\
\text { Rank }\end{array}$ & 39 & 41 & 47 & 49 & 33 & 34 & 40 \\
\hline Vietnam & 2018 & $\begin{array}{l}\text { LPI } \\
\text { Score }\end{array}$ & 3.27 & 2.95 & 3.01 & 3.16 & 3.4 & 3.45 & 3.67 \\
\hline
\end{tabular}

Source: Author consolidated from World Bank 


\section{Macrothink}

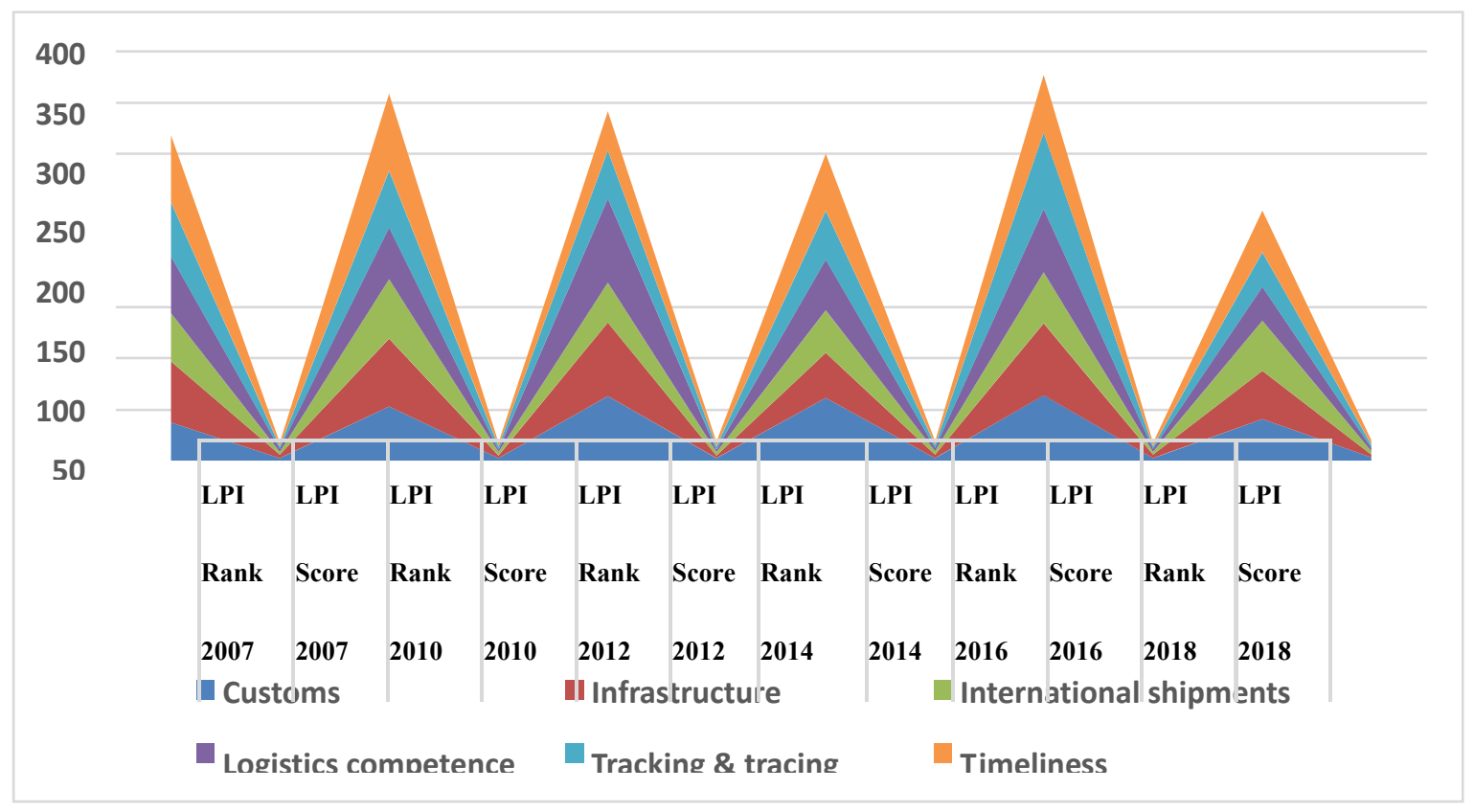

Figure 2. Six factors affect LPI: 2007 to 2018 of Vietnam

Source: The author analyzed and built chart through data sources extracted from the world bank

Table 2: Six factors affect LPI: 2007 to 2018 of Vietnam

\begin{tabular}{|c|c|c|c|c|c|c|c|c|}
\hline Country & Year & & Customs & Infrastructure & $\begin{array}{l}\text { International } \\
\text { shipments }\end{array}$ & $\begin{array}{l}\text { Logistics } \\
\text { competence }\end{array}$ & $\begin{array}{l}\text { Tracking } \\
\text { tracing }\end{array}$ & \& Timeliness \\
\hline Vietnam & 2007 & $\begin{array}{l}\text { LPI } \\
\text { Rank }\end{array}$ & 37 & 60 & 47 & 56 & 53 & 65 \\
\hline Vietnam & 2007 & $\begin{array}{l}\text { LPI } \\
\text { Score }\end{array}$ & 2.89 & 2.5 & 3 & 2.8 & 2.9 & 3.22 \\
\hline Vietnam & 2010 & $\begin{array}{l}\text { LPI } \\
\text { Rank }\end{array}$ & 53 & 66 & 58 & 51 & 55 & 76 \\
\hline Vietnam & 2010 & $\begin{array}{l}\text { LPI } \\
\text { Score }\end{array}$ & 2.68 & 2.56 & 3.04 & 2.89 & 3.1 & 3.44 \\
\hline Vietnam & 2012 & $\begin{array}{l}\text { LPI } \\
\text { Rank }\end{array}$ & 63 & 72 & 39 & 82 & 47 & 38 \\
\hline
\end{tabular}




\begin{tabular}{|c|c|c|c|c|c|c|c|c|}
\hline Vietnam & 2012 & $\begin{array}{l}\text { LPI } \\
\text { Score }\end{array}$ & 2.65 & 2.68 & 3.14 & 2.68 & 3.16 & 3.64 \\
\hline Vietnam & 2014 & $\begin{array}{l}\text { LPI } \\
\text { Rank }\end{array}$ & 61 & 44 & 42 & 49 & 48 & 56 \\
\hline Vietnam & 2014 & $\begin{array}{l}\text { LPI } \\
\text { Score }\end{array}$ & 2.81 & 3.11 & 3.22 & 3.09 & 3.19 & 3.49 \\
\hline Vietnam & 2016 & $\begin{array}{l}\text { LPI } \\
\text { Rank }\end{array}$ & 64 & 70 & 50 & 62 & 75 & 56 \\
\hline Vietnam & 2016 & $\begin{array}{l}\text { LPI } \\
\text { Score }\end{array}$ & 2.75 & 2.7 & 3.12 & 2.88 & 2.84 & 3.5 \\
\hline Vietnam & 2018 & $\begin{array}{l}\text { LPI } \\
\text { Rank }\end{array}$ & 41 & 47 & 49 & 33 & 34 & 40 \\
\hline Vietnam & 2018 & $\begin{array}{l}\text { LPI } \\
\text { Score }\end{array}$ & 2.95 & 3.01 & 3.16 & 3.4 & 3.45 & 3.67 \\
\hline
\end{tabular}

Source: Author consolidated from World Bank.

The chart (Figure 2) and the table 2 give us information of the fluctuation of 6 factors of Vietnam LPI. We can see that although the Timelines scores were significantly high, its IPL ranks were lower than other factors which have lower scores.

Other hand, while customs did not show the significantly during the period from 2007 to 2014 and finally have a peak at 2.95 score in 2018, all other five factors were improved acceptably. For instance, infrastructure improved from 2.5 in 2007 to 3.01 in 2018. Logistics competence and Tracking \& tracing were 2.8 and 2.9 in 2007 had an increase to 3.4 and 3.45 in 2018, respectively. 


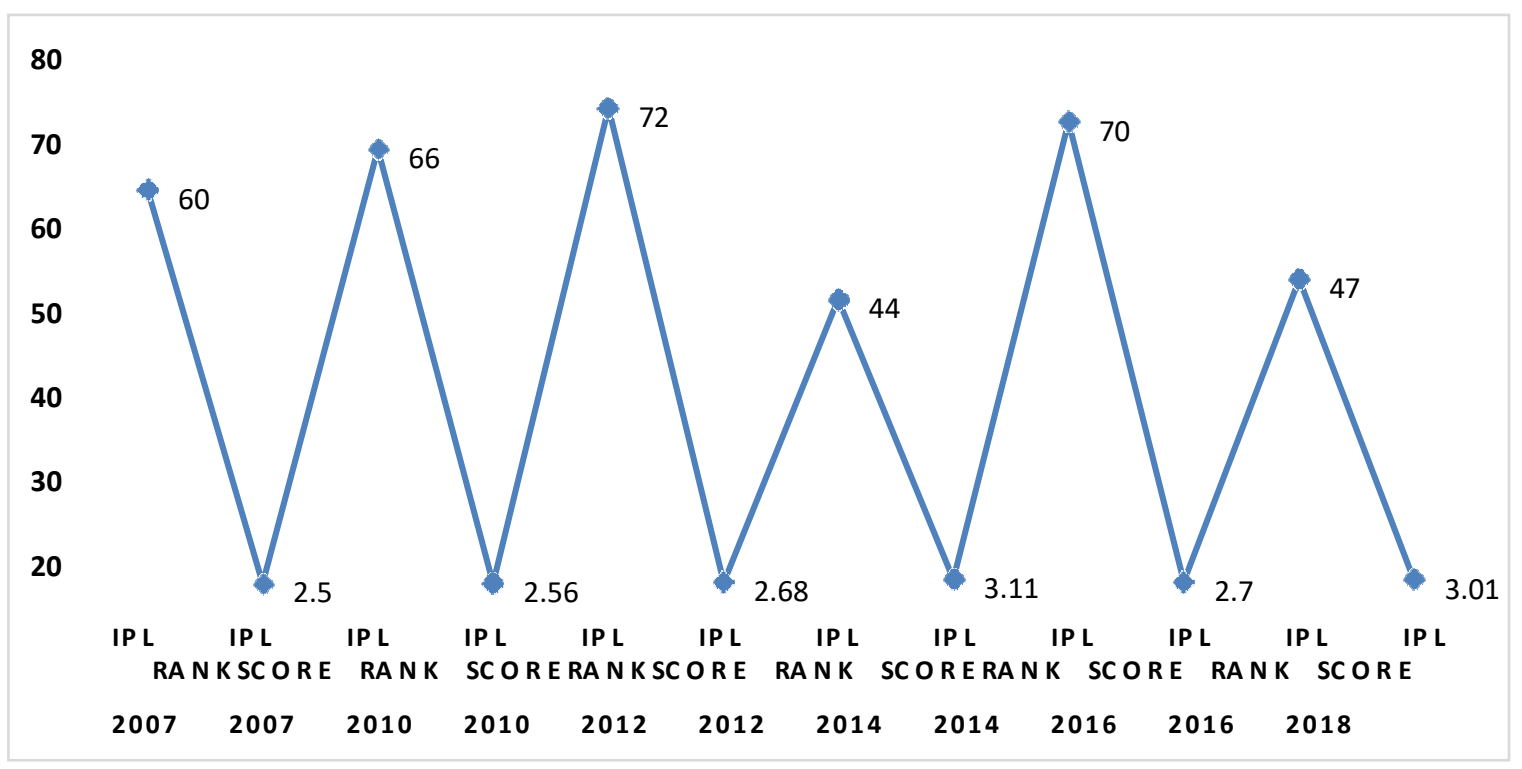

Figure 3. Rank and score of Customs from 2007 to 2018 of Vietnam

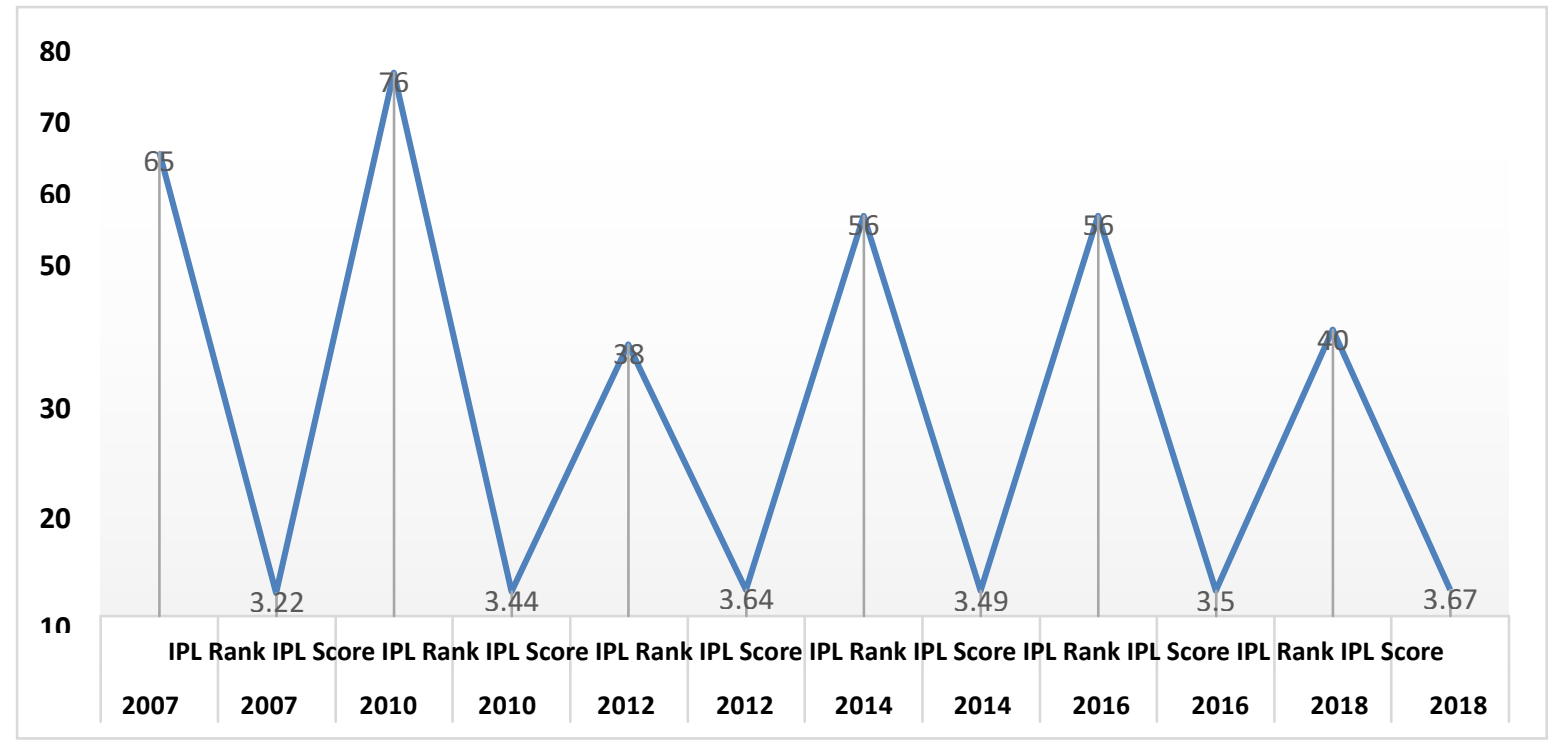

Figure 4. Rank and score of Infrastructure from 2007 to 2018 of Vietnam

Source: The author analyzed and built charts through data sources extracted from the world bank

The chart shows the situation of customs during the period from 2007 to 2018, there was one point unusually is score in 2012 was lower than the one in 2018 but its rank was higher. Nonetheless, rank and score of customs have been significantly improved and reached rank 40 in 2018.

Five 4 describe rank and score of Infrastructure from 2007 to 2018 of Vietnam; while the 
highest score was at the end in 2018 with 3.01, the rank has a peak in 2014.

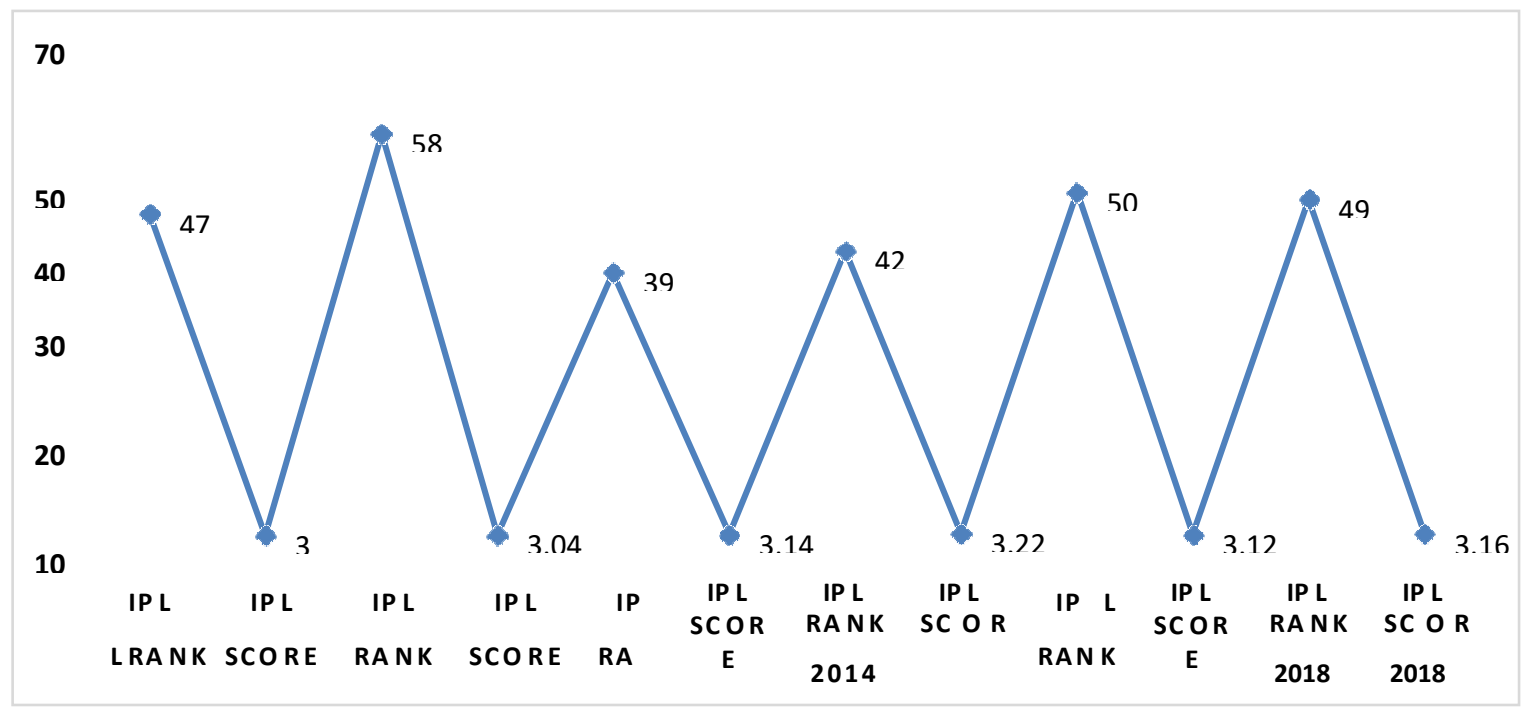

Figure 5. Rank and score of Ease of arranging International shipments 2007 to 2018

Source: The author analyzed and built charts through data sources extracted from the world bank

Looking at the Figure 5, Ease of arranging International shipments was not improved although its score was acceptable.

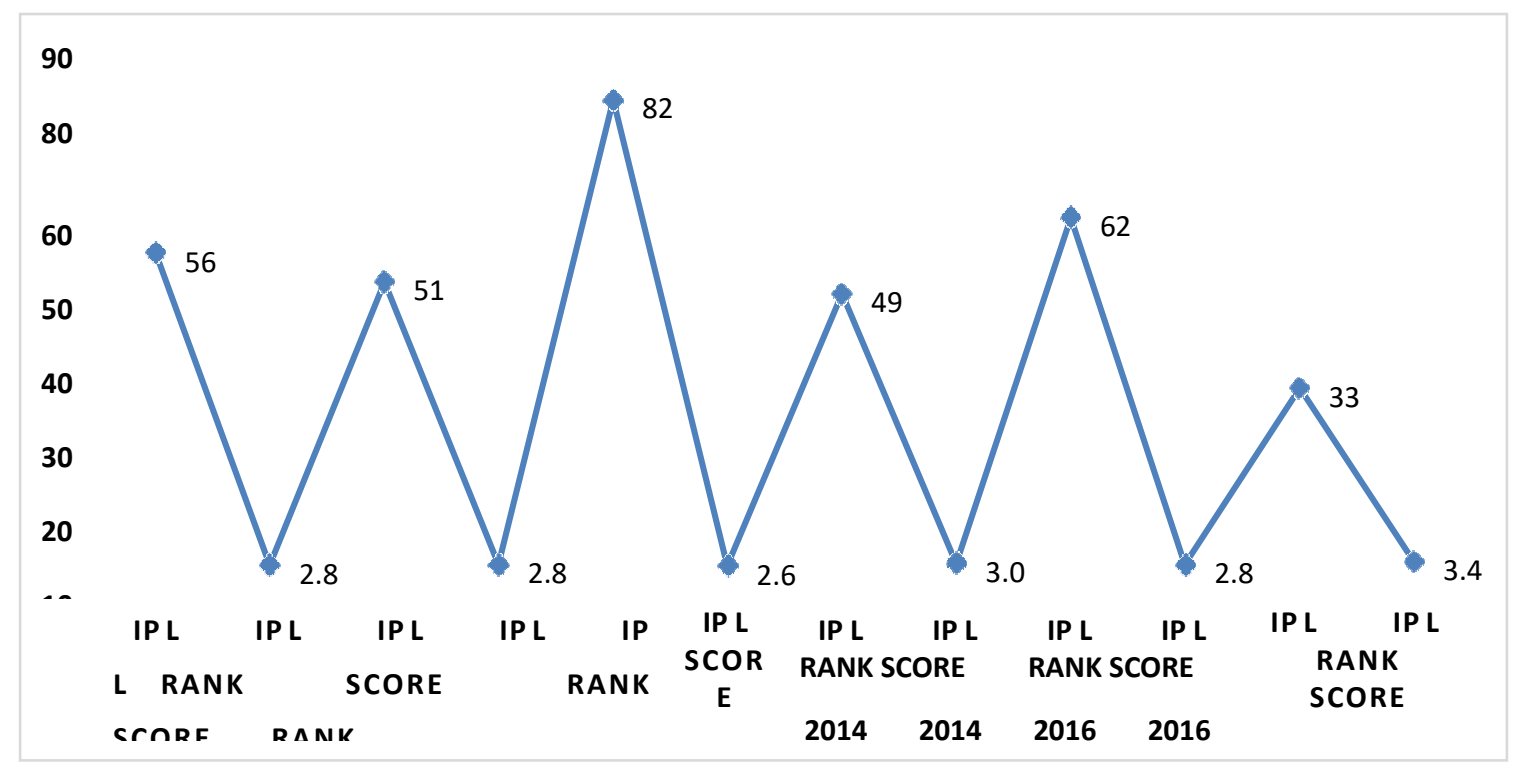

Figure 6. Rank and score of Logistics competence from 2007 to 2018 of Vietnam

Source: The author analyzed and built charts through data sources extracted from the world bank

Figure 6 tells us the bright situation. Despite it was not good in 2012 but strongly improved at the end in 2018 with 3.4 score and rank was 33. 


\section{MInstitute Macrothink $^{m}$}

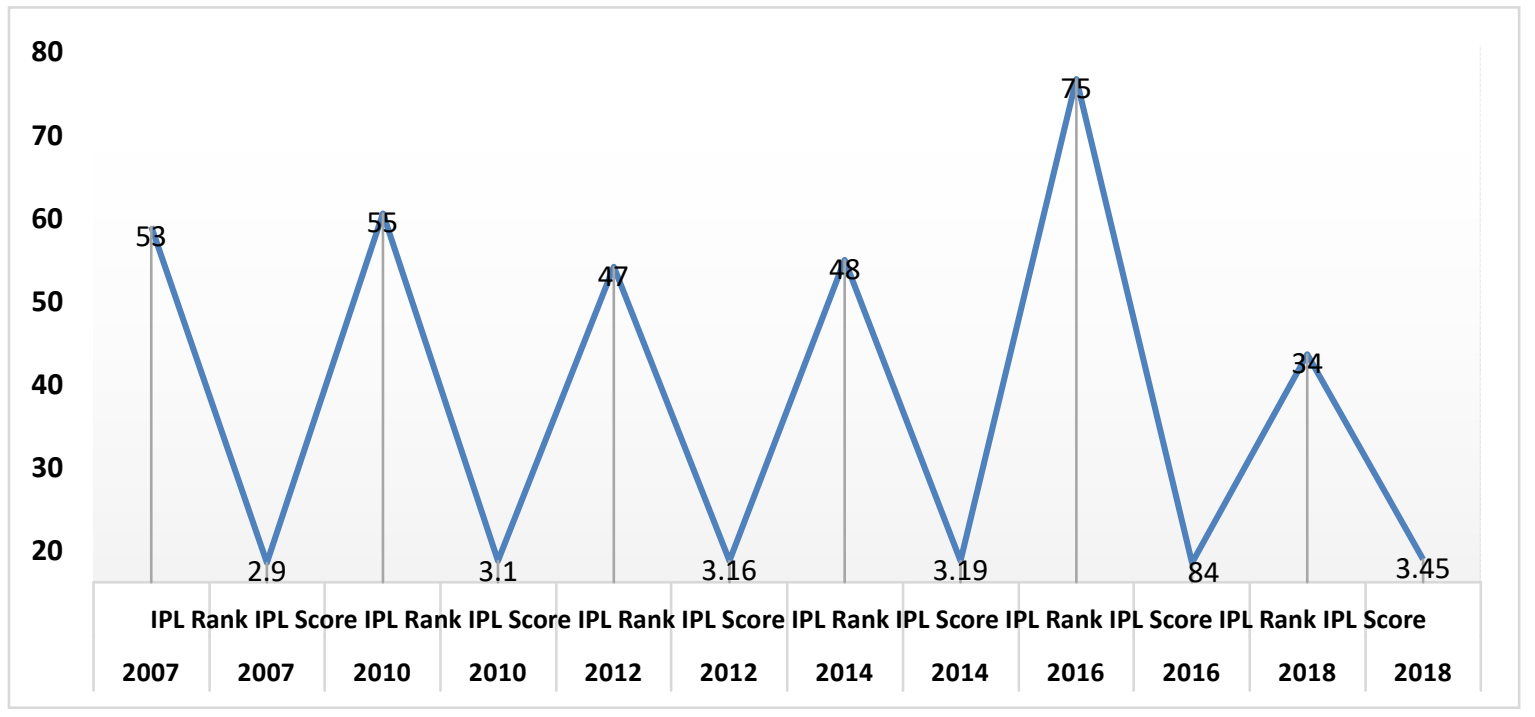

Figure 7. Rank and score of tracking and trace from 2007 to 2018 of Vietnam

Source: The author analyzed and built charts through data sources extracted from the world bank

Similar to Logistics competence through figure 6, giving us clearly the significant improvement between 2016 to 2018, the score was 2.84 at the rank 75, then sharply increased to 3.45 score and shorten 41 steps of its rank, respectively

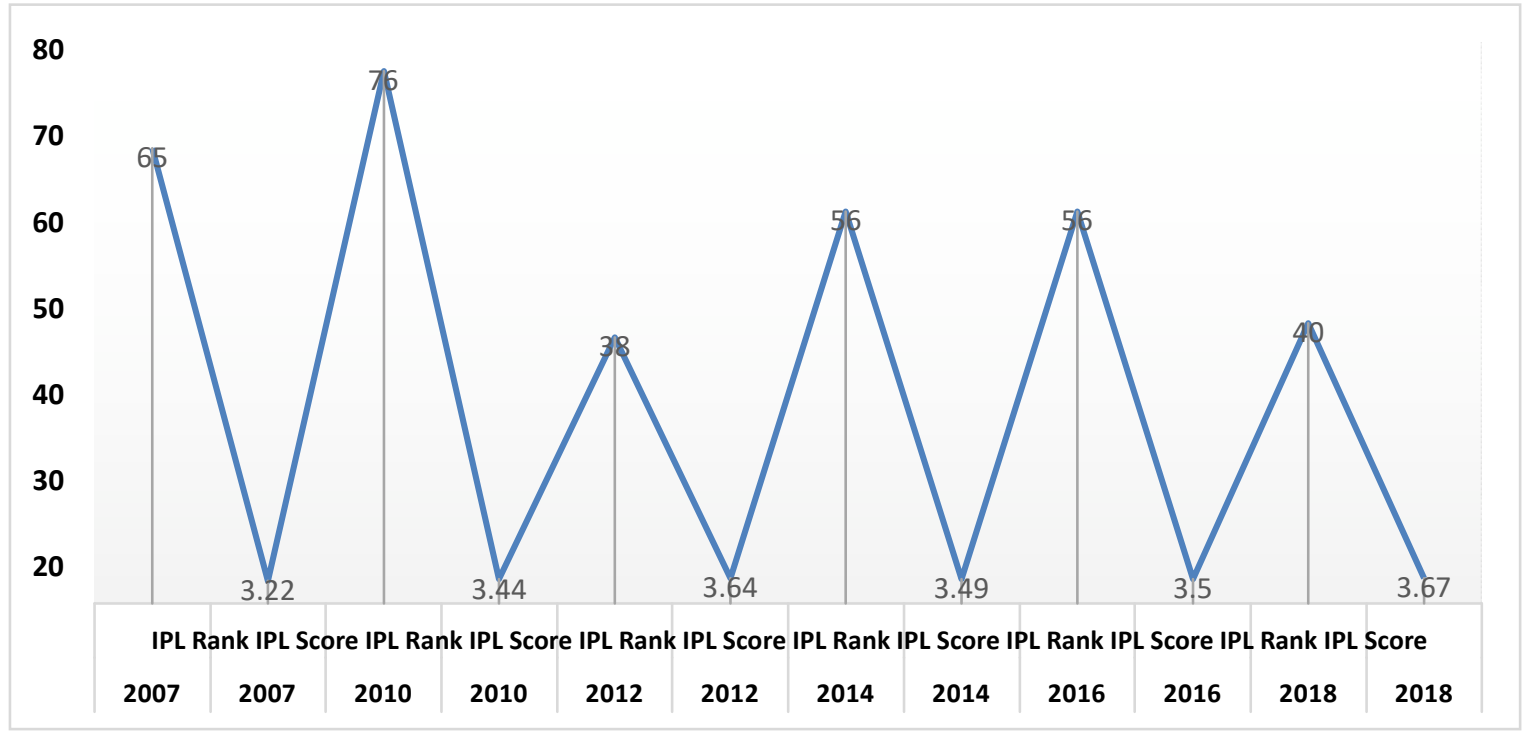

Figure 8. Rank and score of timelines from 2007 to 2018 of Vietnam

Source: The author analyzed and built charts through data sources extracted from the world bank 


\section{Macrothink}

Journal of Asian Development

ISSN 2377-9594

2020, Vol. 6, No. 2

Figure 8 tells us the timelines factor, even though rank level 40 in 2018 is not great, however this is bright and acceptable signal.

\subsection{Multivariate linear regression}

In order to ensure the sufficient size for the samples, the author calculated the time to 2030, and also to predict the ability and fluctuation of Vietnam's logistics competitiveness to 2030.

The results of Multivariate linear regression are below:

Table 3.

\begin{tabular}{|l|l|}
\hline Regression Statistics & \\
\hline Multiple R & 1 \\
\hline R Square & 1 \\
\hline Adjusted R Square & 0.833333333 \\
\hline Standard Error & $5.99265 \mathrm{E}-16$ \\
\hline Observations & 12 \\
\hline
\end{tabular}

We see R square $=1$, Adjusted R Square $=0.8$, which means that $80 \%$ is the variation of the dependent variable depends on 6 independent variables. In other words, $80 \%$ of the competitiveness depends on six factors, they are Customs, Infrastructure, ease of arranging international shipments, logistics competence, tracking \& tracing, and timelines.

Table 4.

\begin{tabular}{|l|l|l|l|l|l|}
\hline ANOVA & $d f$ & $S S$ & $M S$ & $F$ & Significance F \\
\hline Regression & 6 & 6.2085 & 1.03474 & $3.45761 \mathrm{E}+30$ & $2.2457 \mathrm{E}-76$ \\
\hline Residual & 6 & $2 \mathrm{E}-30$ & $3.6 \mathrm{E}-31$ & & \\
\hline Total & 12 & 6.2085 & & & \\
\hline
\end{tabular}

Looking at Table 2 of the above figure, testing the hypothesis of the overall fit of the model, with sig. $=2.25<5 \%$. Prove that $\mathrm{R}$ squared of the population is different from zero. This means that the linear regression model built is consistent with the whole. In more detail, the 


\section{Macrothink}

Journal of Asian Development

ISSN 2377-9594 2020, Vol. 6, No. 2

overall $\mathrm{R}$ square is different from zero, proving that the variables are independent. have impact on the dependent variable.

Tabel 5.

\begin{tabular}{|c|c|c|c|c|}
\hline & Coefficients & Standard Error & Stat & $P$-value \\
\hline Intercept & 0.4206148 & $1.28034 \mathrm{E}-14$ & $3.285 \mathrm{E}+13$ & $5.36969 \mathrm{E}-80$ \\
\hline Customs & 0.1455553 & $4.2974 \mathrm{E}-15$ & $3.387 \mathrm{E}+13$ & $4.47063 \mathrm{E}-80$ \\
\hline Infrastructure & 0.2132948 & $1.805 \mathrm{E}-15$ & $1.182 \mathrm{E}+14$ & $2.47906 \mathrm{E}-83$ \\
\hline International shipments & 0 & 0 & 65535 & \#NUM! \\
\hline Logistics competence & 0.1579632 & 2.65407E-15 & $5.952 \mathrm{E}+13$ & \#NUM! \\
\hline Tracking \& tracing & 0.1224949 & $1.55313 \mathrm{E}-15$ & $7.887 \mathrm{E}+13$ & $2.80446 \mathrm{E}-82$ \\
\hline Timeliness & 0.2229693 & $2.83801 \mathrm{E}-15$ & $7.857 \mathrm{E}+13$ & $2.87026 \mathrm{E}-82$ \\
\hline & Lower 95\% & Upper 95\% & Lower $95.0 \%$ & Upper $95.0 \%$ \\
\hline Intercept & 0.420614786 & 0.4206148 & 0.420615 & 0.420614786 \\
\hline Customs & 0.145555268 & 0.1455553 & 0.145555 & 0.145555268 \\
\hline Infrastructure & 0.213294844 & 0.2132948 & 0.213295 & 0.213294844 \\
\hline International shipments & 0 & 0 & 0 & 0 \\
\hline Logistics competence & 0.157963225 & 0.1579632 & 0.157963 & 0.157963225 \\
\hline Tracking \& tracing & 0.122494895 & 0.1224949 & 0.122495 & 0.122494895 \\
\hline Timeliness & 0.222969301 & 0.2229693 & 0.222969 & 0.222969301 \\
\hline
\end{tabular}

The results in Table 5 show the whole of 6 factors are $>=0$. Therefore, in order to increase 
the competitiveness of Vietnam's logistics industry, it is necessary to increase the scores of these factors. In other words, if Vietnam logistics competitiveness wants to increase, six elements consisting of customs, infrastructure, international shipments, tracking \& tracking and timelines have to be improved.

\section{Discussion and Conclusion}

\subsection{Proposed Solutions to Improve and Enhance the Competitiveness of Vietnam's Logistics Industry.}

To improve the competitiveness of the logistics industry, it is necessary to improve and enhance the capacity, or we can say that it must improve the score of 6 factors, there are some proposed solutions below:

The first: Customs, promote the application of the National Single Window, and the application of the National Single Window to all procedures relating to import, export, transit goods, people and means of transport on entry and exit, transit. Building trade portal, assisting enterprises to search tax rates and import and export procedures related to each item. Develop effective policies to support local logistics development in line with local socio-economic characteristics.

The second: Infrastructure, plans to ensure the synchronization of transport infrastructure and transport services with the objective of developing the logistics service industry. Review and adjust the planning, local production structure associated with infrastructure development and logistics services. Strengthen cooperation with foreign partners to expand logistics infrastructure connection. Invest in expanding logistics infrastructure to connect Vietnam's ports with neighboring countries;

The third: International shipments, Logistics competence, tracking and tracing consignments and timelines: promote the development of multi-modal and cross-border transport, especially for transit goods. Promote transport restructuring to develop a streamlined transport market. Improve shipping capacity. Develop logistics trading floor. Improve logistics infrastructure associated with e-commerce;

Promote the development of multi-modal and cross-border transport, especially for. Promote transport restructuring to develop a streamlined transport market. Improve shipping capacity. Expand cargo by inland waterways. Modernize the railway system and improve the capacity to transport goods by rail. Strengthen the capacity of transporting and handling goods by air. streamline road transport;

Supporting businesses to improve the capacity of negotiation, signing, contract performance, handling disputes related to logistics activities. In-depth integration of logistics services with agriculture, industry, import-export activities, domestic goods circulation and other service sectors, and Promote the construction of 3PL, 4PL logistics services

\subsection{Conclusion}

Today is a flat world, the era 4.0, global economic integration, countries in general and 
Vietnam in particular want to survive, they need to improve their national position, or in other words, they need to improve the index their economy. As introduced, Logistics services increasingly play an extremely important role. Porter (1991), argues that logistics is a functional area that gathering to value creation.

Logistics is a tool to link activities in the global value chain such as supply, production, distribution, and market expansion for economic activities. According to the Council of Supply Chain Management Professionals (CSCMP, 2013). Therefore, improving the logistics industry's competitiveness is a part of the planning and strategy of the Government of Vietnam in general and the Ministry of Industry and Trade in particularly. In order to accomplish this goal, as the author has presented a solution consisting of 3 groups of elements that need to be improved, completed and enhanced, these tasks need to be implemented immediately and must to be accomplished synchronously.

\subsection{The Implication and Limitation of the Study.}

Implication: the significant implication of this paper is that the author had used quantitative research method, using a multivariate linear regression model to analyze the LPI scores which author extracted from the World Bank to explore and prove the influence of six independent $\mathrm{X}$ variables to the $\mathrm{Y}$ variable. In other words, the impact of competitiveness of Vietnam's logistics industrydepends on six factors that are Customs, Infrastructure, international shipments (Ease of arranging shipments), Logistics compentece, Traking \& Tracking, and Timelines. Therefore, this quantitative research method which used the multivariate linear regression model can be used as a proven scientific study, and other authors or the author myself will use this result to study the factors that are sub-factors of six factors, in order to find the core causes of their own value and competitiveness.

Limitation: The limitations of this study is the number of LPI score samples that the author extracted from the World Bank for applying multivariate linear regression models was limited that were just from 2007 to 2018. Therefore, the author had to find out a solution that estimated the figures of LPI scores from 2019 to 2030. Because of estimated figures so that the accuracy is still limited.

\section{References}

Adam, S. (1776). Discuss national assets Adam smith, the wealthy of the nations

Angel, C., Mercedes, L., Juanjo, P., et al. (2020). The facility location problem with capacity transfers. Transportation Research Part E: Logistics and Transportation Review, 138, June 2020, 101943.

Banomyong, R., Thai, V. V., \& Yuen, K. F. (2015). Assessing the national logistics system of Vietnam. The Asian Journal of Shipping and Logistics, 31(1), 21-58.

Bowersox, D. \& Closs, D. J. (1996). Logistical Management: The Integrated Supply Chain Process. New York: McGraw-Hill Companies, Inc.

Capacino, W. C. (1997). Supply Chain Management: The Basics and Beyond Boca Raton. 


\section{Macrothink}

FL.ST.Lucie Press.

Dang, V. L., \& Yeo, G. T. (2018). Weighing the key factors to improve Vietnam's logistics system. The Asian Journal of Shipping and Logistics, 34(4), 308-316.

Decision No. 708 / QD-BCT dated March 26, 2019, on approving the plan to improve Vietnam's Logistics Performance Index.

Decision No.: 200/QD-TTg dated 14 Feb 2017 issued by the Prime Minister of Vietnam in Hanoi, Vietnam.

Directive 21 / TC-TTg of the Prime Minister of Vietnam, dated on 18 July 2018, the instruction on promoting the implementation of solutions to reduce logistics costs, and effectively connect the transport infrastructure.

Donal, J. B., \& David, J. C. (2014). Supply Chain Logistics Management (4th ed.). McGrawhill.

Donald, F. W. et al. (2002). International logistics. AMACOM, US

Donald, W. (2007). Global Logistics - New directions in supply chain management. Kogan Page, UK.

Frazzle, E. (2002). Supply Chain Strategy. McGraw Hill, New York NY.

Gunasekaran, A., \& Ngai, E. W. T (2003), The successful Management of a Small Logistics Company. International Journal of Physical Distribution \& Logistics Management, 33(9), 825-842. https://doi.org/10.1108/09600030310503352

Heskett, J. L., Glaskowsky, N. A., \& Ivie, R. M. (1973). Business logistics: physical distribution and materials management. New York, Ronald Press Co.

Jack G.A.J. van der Vorst, Carlos A. da Silva (2007). Agro-industrial supply chain management: concepts and applications. The Logistics and Operations Research Department of Social Sciences, Wageningen University, Wageningen, Netherlands, Economists of the United Nations Food and Agriculture Organization Rome, Italy, and Associate Professor Jacques H. Trienekens of the Department of Social Science Supply Chain Management, Wageningen University, Netherlands

James, C. J., Donal, F. W., \& Prentice, H. (1998). Contemporary logistics. David J Bloomberg \& Stephen Lemay prentice Hill (2002), Logistics

James, R. S., \& Douglas, M. L. (2011). Strategic logistics management (4th ed.). McGraw-Hill.

John Stuart Mill. (1945). Notes on N. W. Senior's Political Economy

Luis, C. B., John, Isbell, et al. (2014). Effective logistics, the key to Vietnam improve competitiveness, Work Bank (All authors are World Bank officials with contributions from some independent experts). 
Magretta, J. (2012). Understanding Michael Porter: The Essential Guide to Competition and Strategy. Boston: Harvard Business School Publishing.

Mangan, J., Lalwani, C., \& Fynes, B. (2008), Port-centric logistics. The International Journal of Logistics Management, 19(1), 29-41. https://doi.org/10.1108/09574090810872587

Martin, C. (2016). Logistics \& Supply Chain Management $\left(5^{\text {th }}\right.$ ed.).

Maurice, F. N. (1910-2003). American academic, author, and union organizer.

Nguyen, T. T. (2016). An investigation of the Vietnamese shipping industry and policy recommendations for profound participation into ASEAN integration. The Asian Journal of Shipping and Logistics, 32(2), 81-88.

Pan, X., Li, M., Wang, M., et al. (2020). The effects of a Smart Logistics policy on carbon emissions in China: A difference-in-differences analysis. Transportation Research Part E: Logistics and Transportation Review, 137, May 2020, 101939.

Porter, M. E. (1991), Towards a Dynamic Theory of Strategy. Strategic Management Journal, 12(Special Issue), 95. https://doi.org/10.1002/smj.4250121008

Porter, M. E. (1996). What is Strategy. Harvard Business Review, Nov/Dec 1996.

Researchers, P., Edward, S., \& Claudia-Maria, W. (2009). ICT innovation diffusion in small logistics service providers: An empirical survey. National Research Institute of Transport \& Logistics and and the Institute of Technology Research in Dublin, Ireland and University of Naples in Italy.

Resolution No. 02 / NQ-CP of Vietnam Government, issued on January 1, 2019, on continuing to carry out the main tasks and solutions to improve the business environment, enhance national competitiveness in 2019 and orientations to 2021.

Rogers D. S., \& Tibben - Lembke, R. S. (1999). Going backwards: Reverse logistics trends and practices. The University of Nevada, Reno, Center for Logistics Management, Pittsburgh, PA: Reverse Logistics Executive Council.

Ronald, H. B. (). Business Logistics / Supply Chain Management (Fifth Edition, P. 890). Planning, Organizing, and Controlling the Supply Chain. Pearson Prentice Hall Publisher.

Ruslan Beysenbaev and Yuri Dus (2019). Proposals for improving the Logistics Performance Index". The Asian Journal of Shipping and Logistics, Volume 36.

Schumpeter, J. A., \& Opie, R. (1983) [1934]. The theory of economic development: an inquiry into profits, capital, credit, interest, and the business cycle. New Brunswick, New Jersey: Transaction Books. ISBN 9780878556984. Translated from the 1911 original German, Theorie der wirtschaftlichen Entwicklung

Shoshanah, C. (2005). Strategic Supply Chain Management (P. 316). Edward Frazeller McGraw-Hill.

Shoshanah, C. (2005). Supply Chain Strategy (P. 358). Edward Frazeller McGraw-Hill. 


\section{Macrothink}

Journal of Asian Development

ISSN 2377-9594 2020, Vol. 6, No. 2

Shoshanah, C., \& Joseph, R. (2008). Supply chain strategy management. Labor and Social Publishing House.

Simchi - Levi, K. (2003). Designing and Managing the Supply Chain: Concepts, Strategies and Case Studies (p. 354). McGraw-Hill Higher education.

Sy, S. (2016). International Logistics Management. Transport Publishing.

Takanori, S., Adrien, B., \& Adeline, H (2020). Location factors for logistics facilities: Location choice modeling considering activity categories. Journal of Transport Geography, 85, May 2020, 102710.

Volkan Y., \& Yesim Deniz, O.-O. (2020). Logistics centers in the new industrial era: A proposed framework for logistics center 4.0". Transportation Research Part E: Logistics and Transportation Review, 135, March 2020, 101864

Vu, H. N. (2019). The Strategic Development in Logistics in Vietnam. European Journal of Engineering Research and Science, 4(6), 69-73.

Wu, Y. C., Goh, M., Yuan, C. H., \& Huang, S. H. (2017). Logistics management research collaboration in Asia. The International Journal of Logistics Management.

\section{Copyright Disclaimer}

Copyright for this article is retained by the author(s), with first publication rights granted to the journal.

This is an open-access article distributed under the terms and conditions of the Creative Commons Attribution license (http://creativecommons.org/licenses/by/4.0/). 